\title{
Selection of patients for early discharge after acute myocardial infarction
}

\author{
N. C. Chaturvedi, M. J. Walsh, A. Evans, P. Munro, D. McC. Boyle, and J. M. Barber \\ From the Coronary Care Unit, The Ulster Hospital, Dundonald, Belfast
}

We report a prospective study of patients with acute myocardial infarction in whom the use of four simple risk factors allowed the identification of a group of patients who could be safely allowed home on their 7 th day in hospital. This group comprised 40 per cent of all admissions with acute myocardial infarction who survived 6 days. Of these, 68 per cent were discharged by the 7 th day. No patient in this group died in the ensuing 3month period.

Duration of hospital stay after acute myocardial infarction has tended to get shorter over the past 50 years (Rose, 1972; Tucker et al., 1973; Hutter et al., 1973). In a previously reported retrospective study (Boyle et al., 1972), we found that certain simply ascertained factors could select a group of patients with excellent prognosis who could be safely discharged home on the 7 th day.

Since then we have examined these prognostic factors prospectively and have based our discharge policy on them. We now present our experience.

\section{Subjects and methods}

The patients were admitted to the coronary care unit at the Ulster Hospital by mobile coronary care unit or through casualty. Criteria for diagnosis of myocardial infarction and general principles of care have already been described (Walsh et al., 1972). However, in the period covered by the present study oral antiarrhythmic drugs were used more freely after discharge from hospital. Data refer to 275 admissions of acute myocardial infarction involving 253 patients over the period October r97I to September 1972. In each patient the following factors were recorded.

(I) Presence of sustained sinus tachycardia (rate greater than $100 / \mathrm{min}$ ), lasting at least $I$ hour in the first $\mathbf{4 8}$ hours in hospital.

(2) Persistence of ST segment elevation more than $2 \mathrm{~mm}$ in any lead except aVR, six days after infarction.

(3) Occurrence of cardiac pain requiring diamorphine for relief after 48 hours and before 7 days after the infarction.

(4) Occurrence of certain arrhythmias (ventricular ectopics if multifocal, with $R$ on $T$ phenomenon or greater than $5 / \mathrm{min}$, ventricular tachycardia, ventricular fibrillation, second- and third-degree heart block, left or right bundle-branch block) after 48 hours and before 7 days after infarction.

These four factors have been called the 'risk factors'.

Patients in whom none of these risk factors occurred were allowed home by the 7 th day unless social conditions or other medical problems prevented this. Patients

TABLE I Presence or absence of risk factors related to cumulative mortality over following 12 months

\begin{tabular}{llrl}
\hline & $\begin{array}{l}\text { No. of } \\
\text { patients }\end{array}$ & $\begin{array}{l}\text { 3-month } \\
\text { mortality }\end{array}$ & $\begin{array}{l}\text { r2-month } \\
\text { mortality }\end{array}$ \\
\hline All patients (included) & 275 & $12(4 \%)$ & $20(7 \%)$ \\
Sinus tachycardia & $106(39 \%)$ & $9(8 \%)$ & $17(16 \%)$ \\
ST segment elevation & $95(35 \%)$ & $7(8 \%)$ & $10(10 \%)$ \\
Recurrent arrhythmia & $29(10 \%)$ & $8(28 \%)$ & $11(38 \%)$ \\
Recurrent pain & $23(12 \%)$ & $8(25 \%)$ & $12(37 \%)$
\end{tabular}

TABLE 2 Frequency of risk factors related to cumulative mortality from 7 th day after myocardial infarction to subsequent follow-up during 12 months

\begin{tabular}{lccr}
\hline $\begin{array}{l}\text { No. of } \\
\text { risk factors }\end{array}$ & $\begin{array}{l}\text { No. of } \\
\text { patients }\end{array}$ & $\begin{array}{l}\text { 3-month } \\
\text { mortality }\end{array}$ & $\begin{array}{l}\text { I2-month } \\
\text { mortality }\end{array}$ \\
\hline 0 & 109 & 0 & $2(2 \%)$ \\
I & 84 & 0 & $3(4 \%)$ \\
2 & 54 & $4(7 \%)$ & $8(15 \%)$ \\
3 & 28 & $6(21 \%)$ & $7(25 \%)$ \\
Any risk factor & 166 & $11(6 \%)$ & $20(11 \%)$
\end{tabular}


TABLE 3 Distribution of readmissions and reinfarction in relation to risk factors

\begin{tabular}{llcccc}
\hline $\begin{array}{l}\text { No. of } \\
\text { risk factors }\end{array}$ & $\begin{array}{l}\text { No. of } \\
\text { patients }\end{array}$ & $\begin{array}{l}\text { 3 months } \\
\text { Reinfarction }\end{array}$ & Readmission & $\begin{array}{l}\text { I2 months } \\
\text { Reinfarction }\end{array}$ & Readmission \\
\hline No risk factor & 109 & $1(1 \%)$ & $5(4 \%)$ & $5(5 \%)$ & $11(10 \%)$ \\
One risk factor & 84 & $3(4 \%)$ & $10(12 \%)$ & $6(7 \%)$ & $13(15 \%)$ \\
Two risk factors & 54 & $5(9 \%)$ & $10(18 \%)$ & $5(9 \%)$ & $14(25 \%)$ \\
Three risk factors & 28 & $5(18 \%)$ & $6(21 \%)$ & $6(21 \%)$ & $7(25 \%)$ \\
Any risk factor & 166 & $13(8 \%)$ & $26(16 \%)$ & $17(12 \%)$ & $34(20 \%)$ \\
\hline
\end{tabular}

TABLE 4 Cumulative duration of hospital stay

\begin{tabular}{|c|c|c|c|c|c|c|}
\hline & $\begin{array}{l}\text { No. of } \\
\text { patients }\end{array}$ & $\begin{array}{l}\text { Discharged } \\
\text { by } \\
7 \text { th day }\end{array}$ & 8th day & 9th day & Ioth day & IIth day \\
\hline $\begin{array}{l}\text { No risk factor }(\%) \\
\text { Any risk factor } \\
\text { All patients }\end{array}$ & $\begin{array}{l}109(40 \%) \\
166(60 \%) \\
275\end{array}$ & $\begin{array}{r}74(68 \%) \\
30(18 \%) \\
104(28 \%)\end{array}$ & $\begin{array}{r}89(82 \%) \\
46(28 \%) \\
135(49 \%)\end{array}$ & $\begin{array}{r}\text { I03 }(94 \%) \\
61(36 \%) \\
\text { I63 }(59 \%)\end{array}$ & $\begin{array}{l}107(98 \%) \\
102(61 \%) \\
208(75 \%)\end{array}$ & $\begin{array}{l}108(99 \%) \\
107(64 \%) \\
214(78 \%)\end{array}$ \\
\hline
\end{tabular}

in whom any risk factor was present were normally kept at least 9 days. However, because of pressure on beds certain of these patients were discharged earlier. Such patients had good social conditions, had only one risk factor, and had a low acute coronary prognostic index as described by Norris et al. (1969). Patients were reviewed 3 months and 12 months after discharge.

\section{Results}

Overall mortality of patients at 3 months and at I year was 4 per cent and 7 per cent, respectively. The presence of each of the risk factors (Table $I$ ) was associated with a higher mortality. Three deaths were not cardiac.

Table 2 relates mortality to the number of risk factors present. Here it can be seen that ro9 patients $(40 \%)$ had no risk factors. None of these patients died in the following 3 months and 2 died within a year; 84 patients $(30 \%)$ had one risk factor and none of these died within 3 months and the 12-month mortality was low. Patients with two or three risk factors had a high mortality at 3 months and 12 months.

The relation between readmission or reinfarction and the presence of risk factors is shown in Table 3. Readmissions within 3 months of patients with no risk factor were few $(4 \%)$ and only one patient had a further infarction. Patients with risk factors had a higher incidence of readmissions and reinfarction, particularly patients with two or more risk factors. A similar trend was present at 12 months.

Duration of stay in hospital is shown in Table 4. Median duration of stay for all patients was 8 days. Of patients with no risk factors, 68 per cent were discharged by the 7 th day, that is after 6 days in hospital, the remainder staying a short time longer. Patients with risk factors were kept in hospital longer, the median period in hospital being 9 days.

\section{Discussion}

Our previous study (Boyle et al., 1972), using information obtained retrospectively, suggested that the use of simply recognized risk factors would identify a group of patients who could be allowed home as early as the 7 th day. Using them prospectively, we were able to identify a group of 40 per cent of patients with myocardial infarction who could safely be allowed home early. Not only did none of these patients die within the following 3 months but the reinfarction rate and readmission rate were low and the findings at 12 months were also satisfactory.

One unexpected finding was the lower mortality at 3 months in the present study compared with the earlier one (Boyle et al., 1972). In it patients with one risk factor had a mortality of 13 per cent compared with no mortality in this study and in the patients with more than one risk factor, 24 per cent compared with 12 per cent in the present study. Comparing Norris's coronary prognostic index in the two series, the patients in the prospective series tended to have slightly higher values, indicating more severe infarction, so this cannot account for the differences in mortality. A possible reason may be greater care given to patients resulting from our recognition of their increased risk, and in wider 
use of oral antiarrhythmic drugs after the patient's discharge.

We feel that our simple selection procedure allows a significant group of patients to be allowed home safely after only a week in hospital, and so permits a unit to concentrate its resources on patients early in the infarction stage, and for longer periods on patients at an increased risk.

We thank Dr. R. N. Haggan, Dr. D. Gibson, Dr. N. Singh, Dr. R. Ferguson, Dr. B. Singh, and Dr. R. Kumar, who participated during the period of collection of data.

TABLE 4

\begin{tabular}{llll}
\hline I2th day & I3th day & I4th day & $\begin{array}{l}\text { More } \\
\text { than } \\
\text { I4 days }\end{array}$ \\
\hline $108(99 \%)$ & 109 & 109 & 109 \\
$115(69 \%)$ & $122(73 \%)$ & $132(79 \%)$ & 166 \\
$222(81 \%)$ & $230(84 \%)$ & $241(88 \%)$ & 275 \\
\hline
\end{tabular}

\section{References}

Boyle, D. McC., Barber, J. M., Walsh, M. J., Shivalingappa, G., and Chaturvedi, N. C. (1972). Early mobilisation and discharge of patients with acute myocardial infarction. Lancet, 2, 57.

Hutter, A. M. Jr., Sidel, V. W., Shine, K. I., and De Sanctis, R. W. (1973). Early hospital discharge after myocardial infarction. New England fournal of Medicine, 288, I I4I.

Norris, R. M., Brandt, P. W. T., Caughey, D. E., Lee, A. J., and Scott, P. J. (1969). A new coronary prognostic index. Lancet, $\mathbf{I}, 274$.

Rose, G. (1972). Early mobilization and discharge after myocardial infarction. Modern Concepts of Cardiovascular Disease, 4I, 59.

Tucker, H. H., Carson, P. H. M., Bass, N. M., Sharratt, G. P., and Stock, J. P. P. (1973). Results of early mobilization and discharge after myocardial infarction. British Medical fournal, $\mathbf{r}$, 10.

Walsh, M. J., Shivalingappa, G., Scaria, K., Morrison, C., Kumar, B., Farnan, C., Chaturvedi, N. C., Boyle, D. McC., and Barber, J. M. (1972). Mobile coronary care. British Heart fournal, 34, 701.

Requests for reprints to Dr. D. McC. Boyle, Cardiac Unit, The Ulster Hospital, Dundonald, Belfast BTr6 $\mathrm{oRH}, \mathrm{N}$. Ireland. 